\title{
石油化学 と合成ゴム
}

堤

繁
現在は技術革新の時代であり，合成方面では刻々と技 術が変りつつある，石油化学の方面ではとの傾向が特に 大きい，乙の点で石油化学悔 2 期の計画が進んでいる が，この計画を立てるにしても，新しい工場を立てるに して屯，乙の工場が操業を開始する頃には，また新しい 方法加生机て来てい名、したがって，今迄の十年售却か 長くて七年，よくて五年償却という点怔出て来たわけて ある.したがって工場棓画ではこの点についての悩みが 大きく，工場に扣いては現場の問題に取組んでいたので はだめであり，まして大学の㽠究に批いては五年ぐらい は先のことに取組むととが必要となって来る.

そこで，今後合成ゴムの方面でどのような新しい力法 が生れてくるかについて重要な点をあげて諭じてみたい と思います。

第一にブタジエンの問題であるが，ブタジエンを二つ に切るとビ二ルラジカルになります，良って，てのビニ ルラジカルを造ればあとはダイメリゼーション(Dimerization)によってブタジエンになる。そとでてのビニルラ ジカルをどのようにして作るかということであるが，こ のビニルラジカルを得る一例としては，程化ビニルから 塩素をはずすとよである，塩素をはずすためには熱によ る方法, 種々のメタルを用いて，また非常にクラシック な方法ではるるがグリニヤール陚蒋を用いててれをはず す方法线ある。

最近ゴム界ではブタジエンを金属りチウムで重合する という問題むあり最近の種々の有機金属化合物では金属 リチウムが非常にハイライトをあびている。

$$
\begin{aligned}
& \mathrm{CH}_{2}=\mathrm{CH} \cdot \mathrm{Cl} \stackrel{\mathrm{Li}}{\longrightarrow} \mathrm{CH}_{2}=\mathrm{CH} \cdot \mathrm{Li} \longrightarrow \mathrm{CH}_{2}=\mathrm{CH} \\
& -\mathrm{CH}-\mathrm{CH}_{2}
\end{aligned}
$$

ビニルリチウムはー78 〜 $80^{\circ} \mathrm{C}$ て篮化コバルトを作用 させると，ビニルラジカルが生じて容易にブタジェンに なる.とのような可能性ができると次はてれをどのよう 几工業化するかか問題として出てくるのである。

あとにもどって塩化ビニルはエチレンを原料として， エチレンジクロライド（E D C）を作り，とれを500 $\mathrm{C}$

\footnotetext{
* 大阪大学教授
}

(91)
ぐらいで憼分解して作る．とてろがこの中間ビニルラジ 力ルができることが私達の研究室で確かめら扎ており， このビニルラジカルの 2 量化による.ブタジエンの生成 が可能になってくる。

$$
\mathrm{CH}_{2}=\mathrm{CH}_{2} \stackrel{\mathrm{Cl} \cdot}{\longrightarrow} \mathrm{CH}_{2}=\mathrm{CH} \cdot \mathrm{CHCl}
$$

ブタジェンの合成法としては現在日本合成ゴムで行な っているnーブタン定減王化で脱水素する力法が工業的に 行なわれている。しかしイタリアではnーブタンの他にメ タンを原料としてアセチンを作り，これをアセトアルデ ヒドさらにエタノールとして，ブタジンを合成してい る.

イタリアがこの方法を固執しているのはイタリアでは メタンが安洒得ら扎るからである(天然がス $1 \mathrm{~m}^{3} の$ 洒格イタリア，1 月20銭，アメリ力 2 円，日本 6 円).

エニー (Anic) が行なっているのはUCCの方法であ るが，UGC の方法では，メタンを酸素上反応させて， アセチレンを作り，これを濃繀して水銀触媒でアセトア ルデヒドを作り，てれを水絜添加してェ夕ノール变元 て，とのエタノールとアセトアルデヒドからブタジエン を作るのである。

四日市の日本合成ゴムでは終戦後日本のサッマイモを 原料にしてエタノールを作り，このエタノールからブタ ジエンを合成する計画を持っていたが，その後，ブタン 法に变った。

エタノールからブタジエンのできる工程はエタノール からクロメンアルデヒドができて，てれがエタノールか らの水媇で還元されて，つぎ脱水されてブタジエンに なるむのである。

$$
\begin{aligned}
& 2 \mathrm{C}_{2} \mathrm{H}_{5} \mathrm{OH} \longrightarrow \mathrm{CH}_{3}-\mathrm{CH}=\mathrm{CH}-\mathrm{CHO}+\mathrm{H}_{2} \mathrm{O} \\
& \mathrm{CH}_{3} \mathrm{CH}_{2} \mathrm{OH}+\mathrm{CH}_{3}-\mathrm{CH}=\mathrm{CH}-\mathrm{CHO} \longrightarrow \mathrm{CH}_{2}= \\
& \mathrm{CH}-\mathrm{CH}=\mathrm{CH}
\end{aligned}
$$

今後 $n$ ーブタンり外の方法として考穴られるものはエチ レンを原料として，エタノール，アセトアルデヒドそし てブタジエンの線である。

としろがアセトアルデヒドの合成法が变って来た，今 
までアセチレンから造っていたものか，エチレンから作 ら机るようになってきた。これは Wacker 法とよばれる もので，日本でも数社が技術導入により計愄を進めてい る.この Wacker 法というのは次のようにしてアセトア ルデヒドを作るものである。

$\mathrm{CH}_{2}=\mathrm{CH}_{2}+\mathrm{PdCl}_{2}+\mathrm{H}_{2} \mathrm{O} \longrightarrow \mathrm{CH}_{3} \mathrm{CHO}+\mathrm{Pd}+2 \mathrm{HCl}$

金属 Pdになると，もうこれ以上の能力はなくなるの で，塩化水瑟と酸素吹込んで笽化パラジウムを再生す b.

$\mathrm{Pd}+2 \mathrm{HCl}+1 / 2 \mathrm{O}_{2} \longrightarrow \mathrm{PdCl}_{2}+\mathrm{H}_{2} \mathrm{O}$

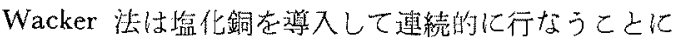
成均している。

エチレンからよ゙のようにしてアセトアルデヒドを作る かというと(これは現在私の研究室で考えられているこ 亡なので，今後变るかも知れないが)，次の上うに説明 することができる。

塩化パラジゥムは次のような量体構造をとっている。<smiles>Cl[Te][Te]Cl</smiles>

ここにエチレンが入ってくると Complex が形成される。

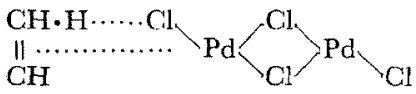

赤外線その优で微測すると 2 重結合力残っている，との コンプレックスが分解するとき $\mathrm{HCl}$ が取れるのである

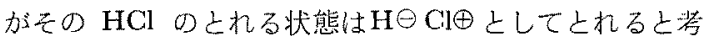
えてビニル円イオンの中間的な生成仮定している，この ビニルやイオンに水が作用するとアセトアルデヒドにな 3.<smiles>[C+]CC(O)C(C)C(C)O</smiles>

先に述ベたイタリアの Anic 社で妒この方法を用いて メタンからアセチレン，アセチレンからエチレン，工チ レンから Wacker 法によりアセトアルデヒド，アセトア ルデヒドからブタジェンを造る計画を具体的にに示して いる。

ここで注意しなければならないのは値段の高いア七チ レンを中間に作ること仙工業的に不利なのでメタンから 直接エチレンを作る方法が今後のびる屯のと思われる。 日本であメタンから直接エチレンを作る可能性が出てく るので、今迄のナフサ加らエチレンを作る点について子 問題加残っている。

次にオーソドックスな $n$ ーブタン法，またはこれに類
似する力法がエチレンからできないからいう䦌題を考え て見る必要がある，現在のエチレンのプラントは年間 4 万トンのものであるが近い将来には年間10万トンのもの ができる、そのようになって来るとエチレンは大変努く なることが予想されるる。こでエチレンから直接にプタ ジンを作ることが考えられるわけである.

证来のシエルの方法はブチレン 2 を dichloride にし て $590^{\circ} \mathrm{C}$ の状態で熱分解してブタジエンを作るむのであ る.<smiles>CC=CC</smiles>

$-2 \mathrm{HCl}$

$$
\rightarrow \mathrm{CH}_{2}=\mathrm{CH}-\mathrm{CH}=\mathrm{CH}_{2}
$$

ところがエチレンからブテンの生成が定量的に行なわ

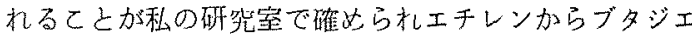
ンの線が出て来ている。

アメリカでは石油会社が石油化学工業をすると損をす るといわれている。日本において化学工業会社が，たと えばエチレンのプラントをする場合にも，事業としては できる限り安全な方法を取るべきであるが，われわれ研 觜者の立場としてはできるだけ新しい方向儿入って行く こ上が建前であり，ここに述べている種々の方法につ ても経斉的な面を別にして考えているわけである。

さて，先ほどのビニルカルボニウムイオン $\mathrm{CH}_{2}=\mathrm{CH} \oplus$ の問題にあどって考えて見よう。このビニルカルボニウ ムイオンの問題が出てくるとエチレンと眽酸ビニルのコ ポリマーの問題む考えられ执ならない，そこで酸酸ビ ニルをアセチレンの代りにエチレンから作ら机るよいう 問題が起ってくる，即ちビニルカルボニウムイオンにア ニネンをつけるととにより，種々のビニル化合物を得る ことができる，たとえばソ連方式につざのようにして酢 酸ビニルを作るものである。

\section{$\mathrm{CH}_{2}=\mathrm{CH} \oplus \stackrel{\mathrm{CH}_{3} \mathrm{COO} \ominus \mathrm{Na} \oplus}{\longrightarrow} \mathrm{CH}_{2}=\mathrm{CHOCOCH}_{3}$}

とのようにして今までアセチレンから作られていたも のがエチレンからできるしいうのが，今後の大きい話題 となって来た

ビニルカルボニウムイオウを中心として，アセチレン とエチレンとからのビニル化合物の生成の関係を示すと つぎのようになる。

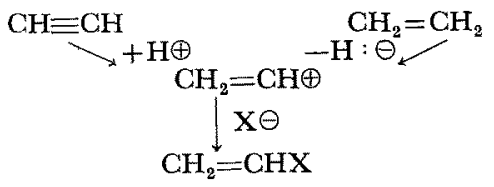


アセチレン上酶酸ビニルの線は酢酸のプロトンがアセ チレンについてビニル・カチオンとなり，またエチレン からH早取ることによって屯同様にビニル・カチオン 加生成する．このビニル・カルボニウムイオン（ビニル ・カキオン) にアセトオキシアニオンがつくと酢酸ビニ ル（ビニルアセテート）となる，現在ではたよえばアセ チレンと酶酸を活性炭にくっつけた釄酸西鉊の触媒を使 って気相で酶酸ビニルを合成している，この気相での反 応機構は䝄かしい問題であるが一応ビニル・カチォンが できていると考えられる。このようにゴム界に限らず今 後エチレン化学が進出してくると学えられる、ゴムの応

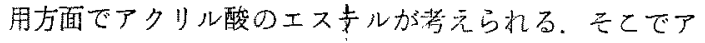
クリル酸の合成が問題よなって来る, 菓亚合成ではアセ チレン, 一酸化宸絜, ニッケルカルボニル，アルコール の線でアクリル酸エステルの合成を行なっている，上述 の関係を考えるとエチレンからでも行くとよが考えられ る. 即ちビニル・カルボニウムイオンに CO がくっつ き,カルボニウムカチオンができて，これでアルコール の $\ominus$ OR がくっついてアクリル酸エステルが合成され る. この場合一酸化炭装は $\mathrm{CO}$ ○であるので容易にくっ ว<.<smiles></smiles>
$=\mathrm{CHCOOR}$

私達のところで塩化ビニルを肺いて同様の反応を確認 している. このようにしてブタジエン，イソプレンの閣 題を飛躍して想像するとかなりの可能性を考えることが できる。

以上の新しい進展は合成ゴムの方面によ゙のような新し い方法を提供するであろうか，むう一度ブタジエンの線 に厣って見てみよう。

\section{a. ブタジエンの問題}

まず，タンからエチレンの線をどのようにのばして ゆくかについて研究の結果老果し述べてみよう，反応機 檴に関してはいろいろの研究が出ていて詳しいことはわ

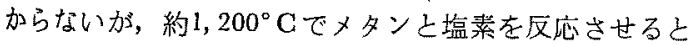
监化ビニルができる，との塩化ビニルのできる考え方は 高温では塩素は塩素原子に解離する．この塩素原子よメ タンの反応によりメチルラジカルが生じ, 生じたメチル ラジカルに笽素が作用してメチルクロライドが生成す る.この場合メタンを過剩使用するとエタンが生成し て，エタンからエタン，エチレンを中間体として塩化ビ ニルができるものと考えられる。

$$
\begin{aligned}
& \mathrm{Cl}_{2} \longrightarrow 2 \mathrm{Cl} \text {. } \\
& \mathrm{CH}_{4}+\mathrm{Cl} \cdot \longrightarrow \mathrm{CH}_{3} \cdot+\mathrm{HCl}
\end{aligned}
$$

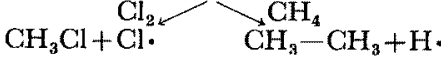

古い文献ではメタンと滥新と酸装とからホルムアルデ ヒドを生成している，とれは滥酸汇よりメ夕ホルムアル デヒドが生成物として上れるが，今後の研究の余地があ る、このようにしてメタンからエチレンの線が出てくる わけであり，乙の点は今後の大きい研究テーマとして残 されている。

先に屯还べたように今後のエチレンからブタジエンの 製造方式としてエチレンからエタノールに行ってアセト アルデヒドに行くか，エチレンからアセトアルデヒドに 行ってエ夕ノールに行くかについては，今後の話題にな ることし思う。

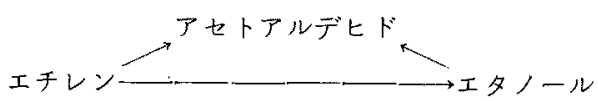

ゴムと関係のないことではあるが塩化パラジウムが出 てくると，檑々の金属八ロゲン化物が再检討さ机て，最 近では夕りウムを使う研垫が出現して来ている。例えば 3 唒のタリウムの使用により，エチレンはエチレングリ コールに変る、現在ではまだ研觉の段階であるが報文に よると3096の収量で酸素を用いることなしにエチレンか らエチレングリコールを得ている，てのようになってく ると，われわ机は塩化パラジウム以外の色令なハロゲン 化合物塩類を用いて，新しい合成法を行なって行く段階 になるであろうと考えられる，夢を見るような話ではあ るがブタジェンの製造方式として侾えられることを迅心 る上，さきほよ゙むいったようにエチレンからのブタジエ ンの製造である. エチレンからブチレンの生成は定量的 に連行する可能性があり，またエチレンから生成するビ ニル・ラジカルは 2 量体化してブタジェンが生成するこ とが認められている。

$$
\begin{aligned}
& 2 \mathrm{CH}_{2}=\mathrm{CH}_{2} \longrightarrow \mathrm{CH}_{3}-\mathrm{CH}_{2}-\mathrm{CH}=\mathrm{CH}_{2}+\mathrm{CH}_{3}- \\
& \mathrm{CH}=\mathrm{CH}-\mathrm{CH}_{3} \\
& 2 \mathrm{CH}_{2}=\mathrm{CH}_{2} \longrightarrow \mathrm{CH}_{2}=\mathrm{CH}-\mathrm{CH}=\mathrm{CH}_{2}+\mathrm{H}_{2}
\end{aligned}
$$

Reppe 化学の古い合成法を考えて見るとてれは1.4ブ タンジオールからブタジェンを合成する。

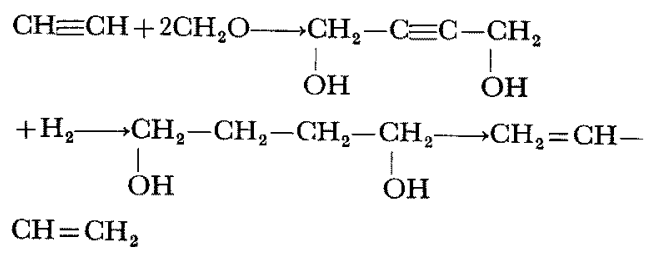

この方法は一眭ドイッでやられたものであるが，この 
方式でアセチレンのかわりにエチレンを使用する研究が なされて，エチレンが使用できるととが明らかになっ t.

つぎに塭化ビニルを用いてのブタジェンの合成法とし てつぎのようなむのが考えられる。<smiles>C=CC(C)CCOCC(C=C)OC(C)C</smiles><smiles>CCCC=CC(O)CC</smiles>

とれに相当する Reppe の化学反応は<smiles>C#CCCOC#CC(C)(O)CC</smiles><smiles>C=CC(O)C[Te]</smiles>

先に述へたように $\mathrm{CH}_{2}=\mathrm{CHCl} \longrightarrow \mathrm{CH}_{2}-\mathrm{CH} \cdot \longrightarrow \mathrm{CH}_{2}$ $=\mathrm{CH}-\mathrm{CH}=\mathrm{CH}_{2}$

この $\mathrm{CH}_{2}=\mathrm{CHCl}$ の $\mathrm{Cl}$ をばすとと，またエチレンか ら H. 取ってビニル・ラジカルを作る技術が工業化す るようになってくる。てれと関連してアクリル酸エステ ルの合成法がまた一歩進んで来ている.

$$
\mathrm{CH}_{2}=\mathrm{CHM} \stackrel{\mathrm{CO}_{2}}{\longrightarrow} \mathrm{CH}_{2}=\mathrm{CH}-\mathrm{COOM}
$$

ここでMはリチウム， $\mathrm{MgX}$ 等である、このような場 合にリチウムが高いという考え老持っているとこのよう な研究はできないわけである。研究の初期に㧧いてはど の上うに高価な試薬を用いても良いのであってともかく 屯可能性を見出すととが必要て放る。一方から考えると このようなメタルの回収を能率よくやるととを考える上

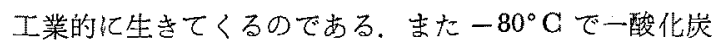
渠を吸込むと難融性のビニルケトンが生じてくる，これ は温度をかけると重合して非常に融点の高い樹脂に変 子.

$$
\stackrel{\stackrel{\mathrm{O}}{\|}}{\left[\mathrm{CH}_{2}=\mathrm{CH}-\stackrel{\mathrm{C}}{\mathrm{C}}-\mathrm{CH}=\mathrm{CH}_{2} \quad \text { ビニルケトン }\right]}
$$

このような瞢のようなことの研究により新しい分野を開 く希望を持っている。ブタジエンの合成はこのような高 㒋な試策を用いて基礎研究を行ないそのつぎに工業化の 問題定考えるわけであるが参考のためにいま述へてきた ような分野があることを申し上げたわけである。

\section{b. イソプレンの問題}

S NRの原料のイソプレンの製造方式としては種々の 方法があるが今のととろこれといったすぐれた方法はな い，従って，ポリブタジエンの方向へ進む力が安全であ るという意見が強いけれどあ, 一応イソプレンの製造法 を取り上げてみよう・イソプレンは $\mathrm{CH}_{3}=\stackrel{\stackrel{\mathrm{C}}{\mathrm{C}}-\mathrm{CH}=\mathrm{CH}_{2}}{\mathrm{CH}_{3}}$ の棈造であるからビニル基をプロピレンにくっつけると 上ができる可能性が出てくる，あう一つの方法としては 炭素数の一つ多い化合物から脱メチルを行なうととに上 りイソプレンに行くことができる.

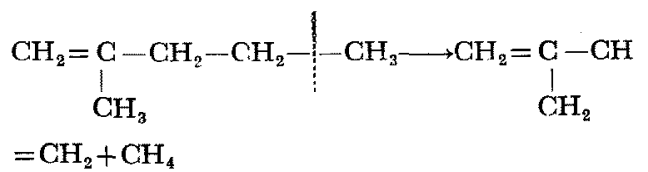

工業的には Prins 反応によりイソブチレンにホルムア デヒドをくっつけて行く方法がヨーロッパではパイロッ トプラントになっており，日本であ計画が進められてい るところがある。そその反応機構はつぎのようである。

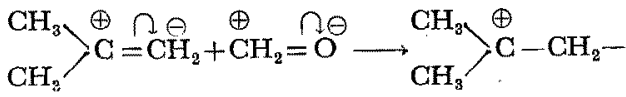

$$
\begin{aligned}
& \mathrm{CH}_{2} \mathrm{O} \ominus \longrightarrow \mathrm{CH}_{2}>\stackrel{\mathrm{CH}_{3}}{\mathrm{C}}-\mathrm{CH}_{2}-\mathrm{CH}_{2} \mathrm{OH} \longrightarrow \mathrm{CH}_{2}=
\end{aligned}
$$

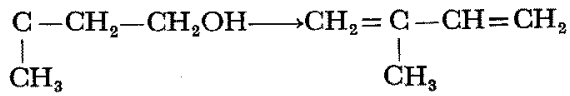

とれは古い歴史を持った工業的に発展しつつある方法 である.今後の新しい分野としてはプロピレンとエチレ ンまなはプロピレンとブテン類という線が出てくるわけ である．問題はこれをよ゙のようにしてやるかである，プ ロピレンとエチレンからの直接合成法はプロピレンの真 中にエチレンをくっつけることである。

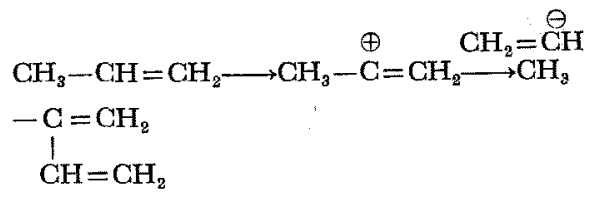

イソブチレンとエチレンからのイソプレンの合成につ いては，外国では $\mathrm{CH}_{3}-\mathrm{CH}=\mathrm{CH}-\mathrm{CH}_{3}$ からであでき るという話があるが招そらく触媒によりイソプチレンに 变わってそれからエチレンが入るるのと考えられる。

それでは ${ }_{\mathrm{CH}_{3}}^{\mathrm{CH}_{3}}>\mathrm{G}=\mathrm{CH}_{2}$ の $\mathrm{CH}_{3}$ をどういうテクニッ クを用いて動かすかというと，最近の新しい分野である が，アルカリメタルにより 2 重結合の $\alpha$ 位を活性化する 
ことができるこよが知られている。たとえば $\mathrm{CH}_{8}-\mathrm{CH}$ $=\mathrm{CH}-\mathrm{CH}_{3}$ のようなブテン類に艅属ナトリウムを作用 させると，2重結合の隣りのメチル基が活性化される。

$$
\begin{aligned}
& \mathrm{CH}_{3}-\mathrm{CH}=\mathrm{CH}-\mathrm{CH}_{3} \stackrel{\mathrm{Na}}{\longrightarrow} \stackrel{\mathrm{Na}}{\mathrm{C}} \mathrm{H}_{2}-\mathrm{CH}=\stackrel{\cap}{\mathrm{CH}}-\mathrm{CH}_{3} \\
& \longrightarrow \mathrm{CH}_{2}=\mathrm{CH}-\stackrel{\mathrm{CH}}{-}-\mathrm{CH}_{3}
\end{aligned}
$$

とのような関係によりイソブチレンとエチレンから

$$
\mathrm{C}-\mathrm{C}=\mathrm{C}
$$

$\mathrm{C}-\mathrm{C}-\mathrm{C}{ }^{2}$ のあのを作り，とれから脱メチルを 行なうととより，イソプレンが作られる。との方法は

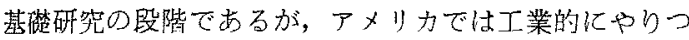
つあるという話毛おる、とのように雨宮博士のやってお られるエチレンとプロピレン(これ枯ナフサ分解のガス がエチレンとプロピレンであるから）教いてイソプレ ンを合成するの手つつの方法であるし，また，エチレン 上イソブチレンからその後脱メチルによりイソプレンを 作る法当若えられる。

古い例であるがアセチレンとエチレンからブタジエン を高湿で作ったものがある，われわ机はとのような高瀑 の問題は考兵られないので，今後の研究題目乞して低温 ての付加芳考えている。

$$
\mathrm{CH}_{2}=\mathrm{CH}_{2}+\mathrm{CH} \equiv \mathrm{CH} \longrightarrow \mathrm{CH}_{2}=\mathrm{CH}-\mathrm{CH}=\mathrm{CH}_{2}
$$

また，最近は種々の触媒が出て来て，イタリヤの $\mathrm{Na}$ tta 一派では土チレンŁブテンを反応させてバナジウム クロライドよアルミニウムトリヘキシルを使用して linearなポリマーを作っている。また塩化ビニルを原料 としてイソプレンを合成した例もある。ひれは塩化ビ二 ルにグリニヤール試薬を働かせて，このも゙ニルグリニヤ ール試薬とアセトンを作用させて，アセチレンとアセト 次応させるの上同様の反応でインプレンを合成して いる.

$$
\mathrm{CH}_{2}=\mathrm{CH} \cdot \mathrm{Cl} \longrightarrow \mathrm{CH}_{2}=\mathrm{CHMgCl}
$$<smiles>CC(C)=[C]CCC(C)(C)CCl</smiles><smiles>C=CCOC(C)(C)C(C)(C)Cl</smiles><smiles>C=CC(=C)C</smiles>

アセチレンとアセトンの反応は<smiles>C#CC(C)(O)C#COC(C)C</smiles><smiles>CCC(C)(C)O</smiles>

アセトンの問題が出たついでに，新しいてセトンの合 成法としてどのような問題があるか在述へてみよう。

今，日本石油化学で行ってい万方法はプロピレンの水 和でイソプロピルアルコールを作って，己れを榄水素す るす法である。これはプロピレンを硫酸に吸わしててれ に水を付加させ，そして水秦をはずしてアセトンを合成 するわけであるが，

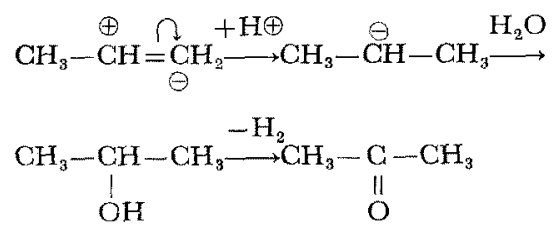

最近の方法はてれを一度にアセトンにする方法で，てれ は協和ガスで技術䜌入が進的られている。

$$
\mathrm{CH}_{3}-\mathrm{CH}=\mathrm{CH}_{2} \stackrel{\mathrm{PdCl}_{2}+\mathrm{H}_{2} \mathrm{O}}{\longrightarrow} \longrightarrow \mathrm{CH}_{3} \mathrm{COCH}_{3}
$$

三非石油化学ではクメン法を用いている。

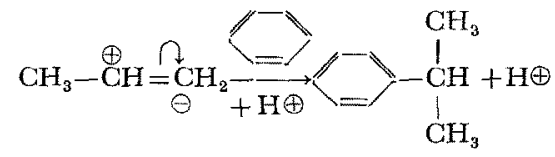

てのクメンを酸化してハイドロパーオキサイドにし て，つぎに酸分解して，アセトン上フェノールを得てい 古.

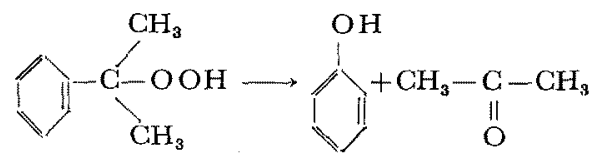

プロピレンから直接にアせトンを得る反応機構はつぎ のようである。

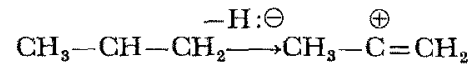

このようにして生じたカチオンに水を嘢かせると，アセ トンのエノール型になる。

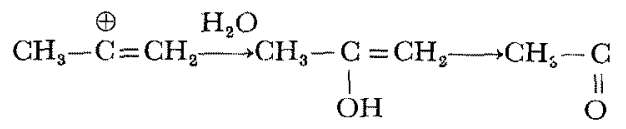

$-\mathrm{CH}_{3}$

最近はとのような $\mathrm{PdCl}_{2}$ ，塩化タリウムを用いる新し い合成方法化進んで来ている，とのようになるとア七ト ンがどれくらいでできるかが問題となる。アセトンとア セチレン加らイソプレンの合成は高いものだという観念 があったが，このようにプロピレンから作られるとなる 上もっとアセトンを用いる方法が進むかす知れない。さ 
らに想像をめぐらすと一つのアイデアが生れて来る。た とえばつぎのようにプロピレンのやにビニルアニオンを くっつけるとイソプレンができるこよが若えられる。

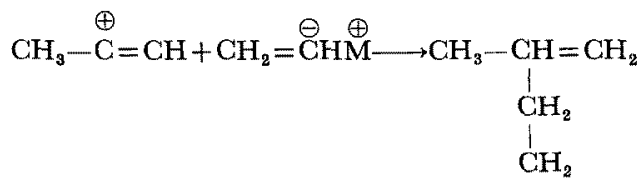

$\mathrm{CH}_{2}=\mathrm{CHM}$ はエチレンまたは塩化ビニルからできる ので一荐の余地がある。こてでプロピレンにおいては $\mathrm{H} \ominus$ が真中から取れたのであるがブチレンではよ゙うなる であるうか，てれも同様に

$$
\mathrm{CH}_{3}-\mathrm{CH}=\mathrm{CH}-\mathrm{CH}_{3} \longrightarrow \mathrm{CH}_{3}-\stackrel{\oplus}{\mathrm{C}}=\mathrm{CH}-\mathrm{CH}_{3}
$$

これに水が作用すると

$$
\begin{aligned}
& \mathrm{CH}_{3}-\stackrel{\oplus}{\mathrm{C}}=\mathrm{CH}-\mathrm{CH}_{3} \stackrel{\mathrm{H}_{2} \mathrm{O}}{\longrightarrow} \mathrm{CH}_{3}-\underset{\mathrm{OH}}{\mathrm{C}}=\mathrm{CH}-\mathrm{CH}_{3} \\
& \longrightarrow \mathrm{CH}_{3}-\underset{\text { II }}{\mathrm{C}}-\mathrm{CH}_{2}-\mathrm{CH}_{3}
\end{aligned}
$$

L支る.

さて、フェノールの新しい方法ししては先程のタメン 法が出罖したのであるが，最近また新しいフェノールの 合成法が出て来た（彷来のフェノールの合成法はベンゼ ンをスルホン化してアルカリで炕理して作る)，最近現 われた新しい方法というのは安息香酸を酸化して作る力 法である，安息香酸はトルエンを五酸化バナジウム触媒 で作ることが出来る，普通酸を酸化すると炭酸ガスと低 級な炭化水素に分解するのが常識なのだが，この安息香 酸を酸化すると安息香酸のフェニルエステルを経てフェ ノールになる。

$$
\begin{aligned}
& \mathrm{C}_{6} \mathrm{H}_{5} \mathrm{COOH} \longrightarrow \mathrm{C}_{6} \mathrm{H}_{5} \mathrm{COOC}_{6} \mathrm{H}_{5} \stackrel{+\mathrm{H}_{2} \mathrm{O}}{\longrightarrow} \mathrm{C}_{6} \mathrm{H}_{5} \mathrm{COOH} \\
& +\mathrm{C}_{6} \mathrm{H}_{5} \mathrm{OH}
\end{aligned}
$$

強媒としては銅を用いる。または安息香酸しCupricな 塩類を用いて行なう。安息香酸の銅程 $\left(\mathrm{C}_{6} \mathrm{H}_{5} \mathrm{COO}\right)_{2} \mathrm{Cu}$ を200〜 $250^{\circ} \mathrm{C}$ で熱分解する上炭酸ガス在出して安息香 酸のフェニルエステルができる、Cupricな安息香酸の塩 はつぎのような構造をあっている。

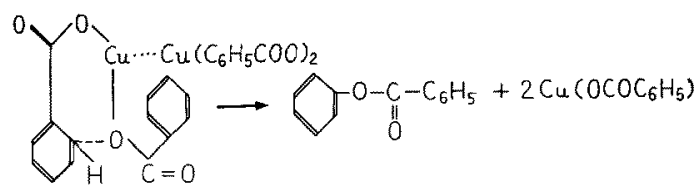

以上はトルエンの利用について述べたのであるか，つ ぎにキシレンの利用について考えて見よう。現在テレフ タル酸の用逾がのびているので $p$ キシレンの需要は大 きいが $m$-キシレンは需要が少ない（あっとも $m$-キシ レンの樹脂での利用は工業化される段階になっている が)・mーキシレンを酸化すると $m$-トリル酸になる、乙れ

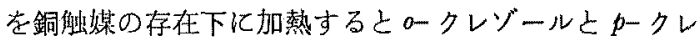
ゾールとになる。また， ルを得る。
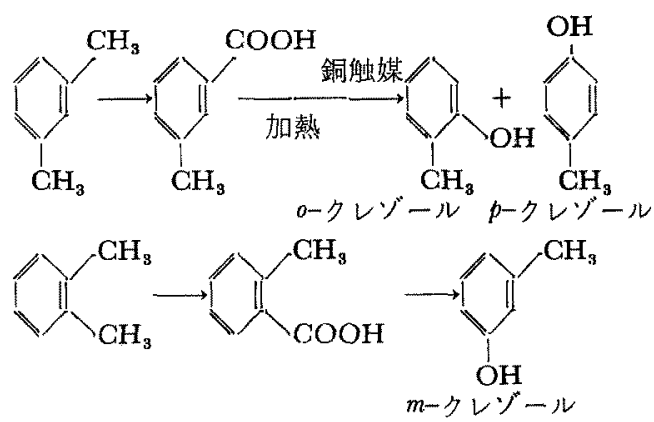

\section{c. スチレンの問題}

スチレンは一般にベンゼンとエチレンからエチルベン ゼンを作り，てれを脱水素して工業的に合成されてい る. また，一方変わった方法としてはエチルベンゼンを

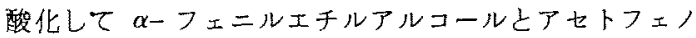
ンとなり後者を水素添加して全部を $\alpha$ フェニルエチル アルコールとして，てれを脱水してスチレンを得る。

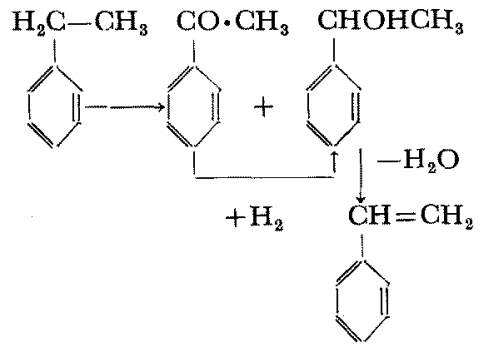

こ机は見在具体的に行なわれている，われわれはエチ レンとベンゼン，または塩化ビニルとベンゼンから直接 的にスチレンを合成しようと考えている，製鉄会社ての 他ではコークス炉ガスに数％含まれているエチレンを濃 液して，塩化ビニルを合成する。また石油化学の主原料 であるエチレンを用いて塩化ビニルの方向に利用する計 画をしている．私の研究室で行なっているナフサ分解に より，ナフサと酸䋜を部尔燃邺して，アセチレンとエチ レンを作る，乙の場合に得られるものの濃度はうすくて アセチレンの場合は10\%内外，エチレンの場合も10〜14 タぐらいのすのである，とれを辴縮していると高いあの になるので，濃縮しないでそのまま塩ビに変えると，塭 化ビニルをかなり安く拳敒入ることができる。したが って，私の考えでは薄いエチレン，アセチレンからその まま塩化ビニルに変えればてれは凝樎できるからててれ を出発原料とすべきであると思う，ベンゼンと塩化ビ二 ルから現在のところ収量は良くないが，スチレンの合成 
㗹められている，このうにビ二ル化合物を直接に合成 することは眮味あるとではあるが，工粎的に行なう場合 には種ヶの問題を含んでいる，一例を上げれば塩化ビ ニルを用いると塩酸が出てくるのであるが，乙の処理を どのようにするかといった問題がある.

\section{d. ベンゼンの問題}

ベンゼンの構造には種々の共沜構造が存在する，その うちにラジカル反応に関与してくるものはつぎの $2 つ 0$ 型のベンゼンである⿸丆口。<smiles>C1=CC(=CC2CC3CC2C3)CCC1</smiles>

この構造を見ると、とれらが重合を起さないかという 問題が当然起ってくるわけである。さらに，一つの新し い分野としてはベンゼンに 3 電綃合を持った化合物が存 在ずるとよである.

$$
\text { || }
$$

ナフタリンでもとのような型は当然存在する。<smiles>C1CCC2CCCC2C1</smiles>

とのようなベンゼンの diradical 的な新しい分野の問 題はこれらが重合しないかというわけであるが，現在で はある程度の重合が可能になっている。たよえば<smiles>[C]1C=C[CH]CC1</smiles>

りような型をしているとつェニルラジカルにより重合す ると思われる．とれにフェニルラジカルが入ると<smiles>CC1C=CC(=C2CCCCC2)C=C1</smiles>

になる。ささらに、良いテクニックを施すと，てれが重合 するねけであるか，この場合は 2 量化して

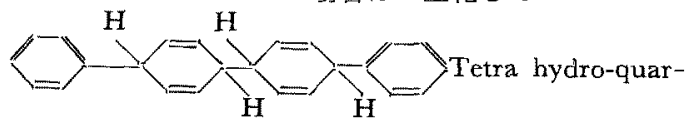

ter-phenyl

になる。

これは扣熱により容易にベンゼン核にあどってQuarter-phenyl よなる。

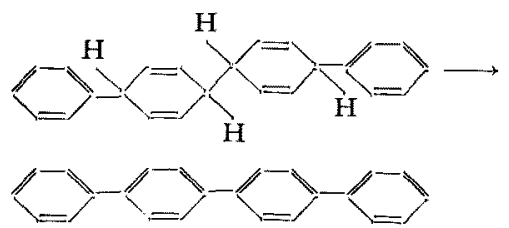

また，r線その他によりベンゼンを直接重合すること 6諰めら机て扣り，現在ベンゼン核にして 8 個はどのも のができている。
つぎにベンザインの雷合であるが，このベンザインは 3 重結合を持つているから容易にフェノ一ルに変わる。<smiles>CO[As]1(c2ccccc2)CCCC1</smiles>

このベンザインはクロルブンゼンから腹体アンモニア 中でンーダアマイドを用いて脱八ロゲ化水素により作 る.この 3 重結合物はあちろん取り出されてはいないか， こ机が中間にできているいるな反応を起す上考えられて 㕲り，李してのベンザインが容易にできるようにな机 ば，とれらを重合させることが考えられるのである。べ ンザインは，つぎの靚造のように diradical 的な化合物 上考齐ら机<smiles>Brc1ccccc1</smiles>

これらの重合により2 重結合の残ったまま 8 個が環状に つながったつぎのような化合物が得られている。

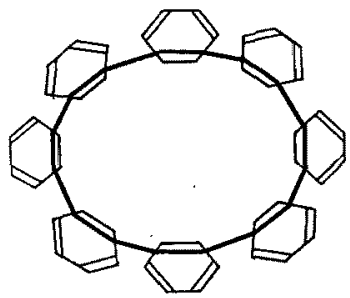

Octa-phenylene

ようにこの方面で夢を進めるよトルエン，p-キシレン心゙ 重合の問題が出てくる。<smiles>CCCc1ccc(CC)cc1</smiles>

今後，てのようなポリマーも奏現しそうである。

以上故合成原料としてのオレフィン，アセチレン，心 ンゼンについてのべて来たのであるが，A後さらに考え なりればならないものとして一酸化炭素の利用の問題が ある，一酸化炭素は現在アンモ二アの合成，メタノール の合成，またさらにメタノールからホルマリンーデルリ ンの線で活用面が見出されているが，依然として莫大な 量が出てくる. 一酸化炭素の新しい面としてはイソシア ネート，エチレンとのコポリマーさらには一酸化岸素之 水からポリチレンの竪造の問題がある、一酸化素素と ポリメチレンの合成む考えら执な执ならない，プロ ピレンと一酸化炭素加ノルマルブタノール，ビニルリ チウムと一酸化炭素からビニルケトン，さらにビニルケ トンからポリマーの問題むある。酸化炭素とアンモ二

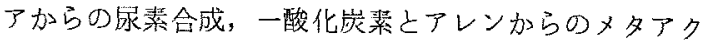
リル酸の合成等しのように一酸化炭美は今後の合成化学 の原料上して十分考えら机ばなら好6のである。これ 上並んで炭酸ガスもまた, 㨁接にカルボン酸を合成する 万向に進められている。 